\title{
Food safety: relation between pesticides and poisoning
}

\author{
Vinícius Gonçalves LOPES ${ }^{1,2 *}$ (D), Guilherme Nobre Lima do NASCIMENTO ${ }^{1,2}$
}

\begin{abstract}
Brazil has worldwide relevance in agriculture, as well as being one of the largest consumers of pesticides. This reality associated with underreporting of poisonings, food sample data above the permitted limit of current legislation, possible pesticide flexibilities and increasing smuggling of these products. This study aimed to evaluate the marketing situation in the various regions of Brazil, as well as to relate to the reality of poisoning notifications. It was evaluated in the literature, in the notification systems data platform, statistical tables and commercialization of these products from 2013 to 2017. The reality found was the annual gradual growth in most regions, being the Midwest region with the highest index in 2017 with an average of 180 thousand tons of assets. Among the most commercialized we have the 3 main ones: Glyphosate and its 2,4-D and Mancozebe salts, being classified by Brazilian Institute of Environment and Renewable Natural Resources (IBAMA) as dangerous (class III). Regarding poisoning, there are discrepant results among notification systems, with Notifiable Diseases Information System (SINAN) having better information with 37 cases in Brazil, while in National Toxic-Pharmacological Information System (SINITOX) in 2017 there is no notification data. A reality with scarce data regarding food poisoning.
\end{abstract}

Keywords: pesticides; food safety; intoxication.

Practical Application: To subsidize data to analyze the pesticide trade and possible interferences in the quality of food produced.

\section{Introduction}

Brazil stands out in the export of agricultural products, having relevance in world agriculture. The use of pesticides increased as a result of the need to eliminate plant pests, as they harmed food and affected its commercialization (Caldas, 2016; Gaboardi et al. 2019).

In the last decade, according to IBAMA (Instituto Brasileiro do Meio Ambiente e dos Recursos Naturais Renováveis, 2017) the consumption of pesticides in Brazil has been highlighted by the increase, being in 2017 reaching the mark of 540 thousand tons traded, making it with world leading position in the use of these inputs. It is allied to the reality that each year, new pesticide assets are released for commercialization, that is, new environmental risks and public health.

The marketing of pesticides in Brazil is governed by Law 7.802/1989 (Brasil, 1989), regulated by Decree 4.074/2002 (Brasil, 2002) which describes environmental, public health and agronomic performance criteria, being considered as stricter regarding the registration of pesticides (Brasil, 2002). However, a bill (PL 3,200/2015) runs in the National Congress to approve and to amend the current law, which, considering that the legislative achievements are considered a setback, since it relaxes the Brazilian legislation in addition to minimizing the conception of toxicity of these assets to human health and the environment (World Health Organization, 2010; Pelaez et al., 2010).

Relating the high trade present in our country, possible registration flexibilities, growing black market of pesticides, research evidencing irregularities in quality control in water and food for consumption, relevance of acute and chronic intoxication rates of the population, work environment risk to agricultural workers, highlights the urgency of improving public policies regarding the monitoring of the production chain of these products aiming at the protection and promotion of health (population and environmental) (Londres, 2011; Rigotto, 2011; Da Ros, 2019; Klanovicz, 2010; Brasil, 2016b).

The exposure of the general population to pesticides has some introduction routes, to be it by mouth, which will be through ingestion of contaminated food and water, respiratory and dermal, often found in the case of domestic or agricultural spraying, as well as inhalation during spray application. In the case of food intake, the load of these assets present in these products will directly affect their quality and putting the citizen in acute and chronic exposure (Santos et al. 2018). In the airway, its route of exposure is wide, in which toxic inhaled gas is easily distributed in much of the organism causing harmful and lethal consequences to the lungs and other organs (Silva \& Costa, 2018)

The Notification Disease Information System (SINAN) is one of the tools with stored data pertinent to the poisonings caused by pesticides. In mid-2013 to 2017, 24,148 cases of agricultural pesticide poisoning were reported, and underreporting is a present reality, camouflaging the magnitude of the problem in question (Datasus, 2019; Almeida et al. 2017).

${ }^{1}$ Programa de Pós- graduação em Ciência e Tecnologia de Alimentos - PPGCTA, Universidade Federal do Tocantins - UFT, Palmas, TO, Brasil

${ }^{2}$ Laboratório de Ciências Básicas e Saúde - LACIBS, Universidade Federal do Tocantins - UFT, Palmas, TO, Brasil

*Correspondig author: vglopes06@gmail.com 
Therefore, given the reality of distribution, control in the use of these inputs and incidence that the population is exposed daily, this paper aims to analyze indicators that demonstrate the reality of commercialization, as well as to observe the relation of poisoning rates.

\section{Materials and methods}

A literature search was performed in the databases PUBMED, Science Direct, Scielo, Google Scholar, and survey of poisoning data recorded in the Notification Disease Information System (SINAN WEB) through the DATASUS platform, SIDRA/ IBGE statistical table database, IBAMA and the National Poisoning System (SINITOX) from January to March 2019.

As a facilitator of the process the descriptors were used: "Pesticides", "Marketing of Pesticides", "Endogenous Pesticide Poisoning", "Legislation and Market on Pesticides", "SINAN", "IBAMA", "SINITOX", "Pesticide" and "Toxicity", in Portuguese and English, published from 2010 to 2019, with the exception of legislations and manuals published prior to the analyzed period.

The survey of statistical data on marketing of pesticides and poisoning cases were conducted from 2013 to 2017, and this last year with data made available by digital platforms.

\section{Results and discussion}

Evaluating data regarding the commercialization of pesticides in Brazil, observed in Figures 1 and 2, there is an annual growth in their commercialization, with 2017 having the highest active ingredient commercialization rates reaching almost 540 thousand tons, which represents about $10 \%$ growth in these years.

In the current scenario, the Midwest region had the greatest relevance in the use of these products in all years analyzed reaching in 2016 the record with an average of 185 thousand tons, representing $34.24 \%$ of national trade, then following the southern region which had the highest commercialization rate in 2017, with 165 thousand tons of active ingredient reaching $30.61 \%$ of the national market. This reality was demonstrated by Pignati et al. (2017), being MT (Mato grosso), the state with the largest soybean and corn plantation in the country, as well as the one that consumed the most pesticides in 2015, therefore, having essential weight in the consumption of these substances.

Between 2015 and 2016, there is a decrease in the marketing of these substances in the southern $(0.31 \%)$ and southeast $(6.31 \%)$ regions, a similar reality identified in a study on the profile of pesticide use in Southwestern Brazil. Paraná performed by Gaboardi et al.(2019), in which they presented official data of growth in previous years and fall in 2016, suggesting as a hypothesis of this smuggling due to proximity to the border, other hypotheses were listed; however, they were not made, specific studies to prove them such as: reduction in agricultural production, reduction by improvement of management technique or some kind of inconsistency in the data.

According to Figures 1 and 2, the results are observed for the commercialization of "undefined" products, and in IBAMA platforms, there is justification that these products do not have a definition of the region/place of sales. Over the years these results have gradually decreased reaching lower data in 2017 with $3.96 \%$ of national demand, which is still a relevant value, due to the lack of knowledge of the origin of these products, but improvements can be seen in the inspection and marketing system for these products.

Table 1 below describes the 10 most sold active ingredients each year of the study period, and glyphosate and its salts were the main assets sold in each year, reaching the highest consumption in 2015, approximately 195 tons of active.

Significant values are justified because it is the main product used in soybean and sugarcane crops, in which Brazil is prominent worldwide for its cultivation (Pignati et al., 2017). Then, 2,4 - Dichlorophenoxyacetic Acid (2,4 -D), which in 2017 reached

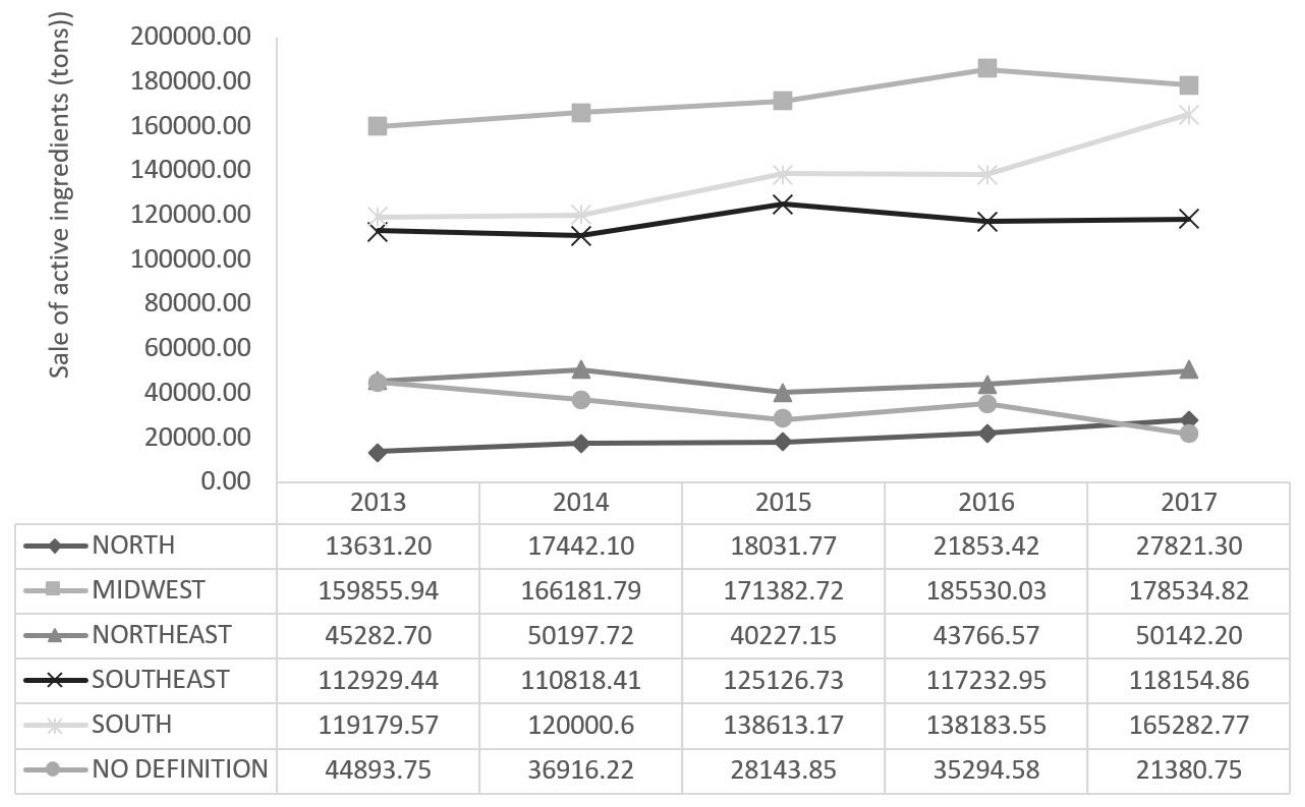

Figure 1. Commercialization of pesticides in Brazil (by region) from 2013 to 2017. Source: IBAMA. 


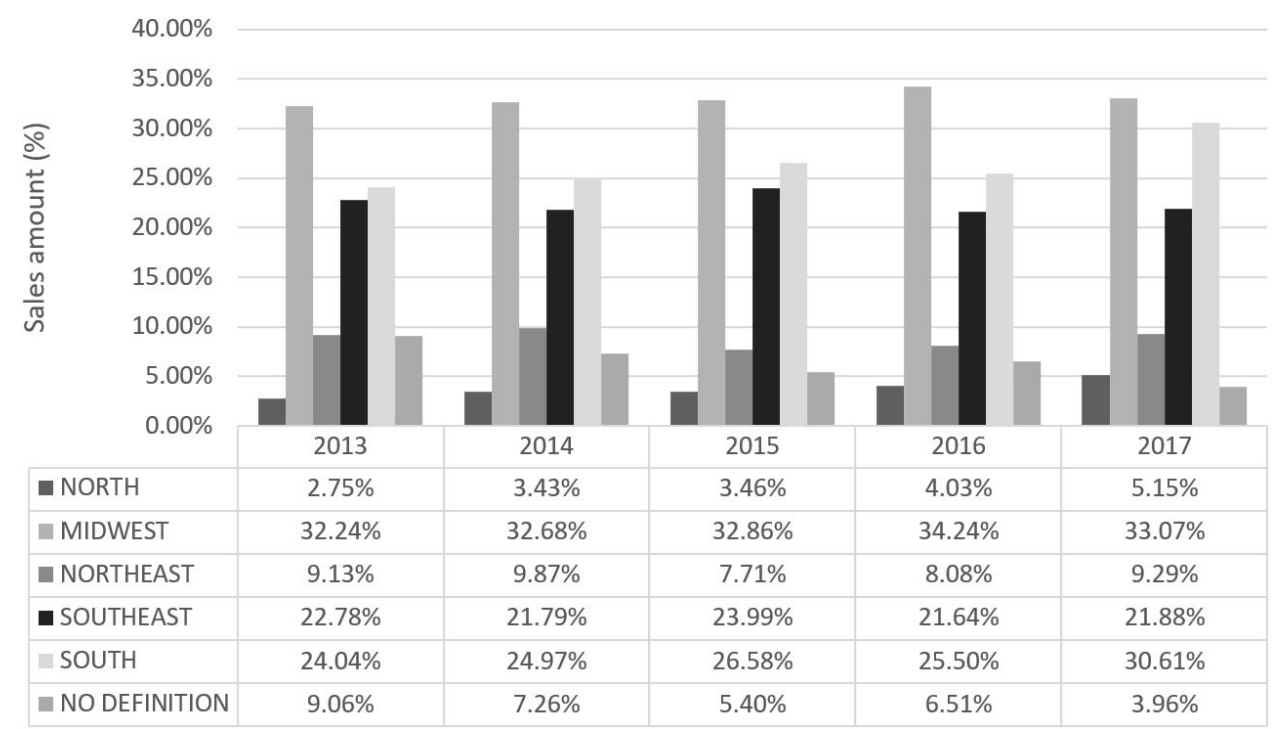

Figure 2. Representation (in \%) by region in the national marketing of pesticides. Source: IBAMA.

Table 1. The best-selling active ingredients in Brazil from 2013 to 2017.

\begin{tabular}{|c|c|c|c|c|c|}
\hline Year & $2013^{*}$ & $2014^{\star}$ & $2015^{\star}$ & $2016^{*}$ & $2017^{\star}$ \\
\hline Glyphosate and its salts & $185,956.13$ & $194,877.84$ & $194,939.60$ & $185,602.22$ & $173,150.75$ \\
\hline $2,4-\mathrm{D}$ & $37,131.43$ & $36,513.55$ & $48,013.26$ & $53,374.41$ & $57,389.35$ \\
\hline Mancozebe & $8,419.01$ & $12,273.86$ & $21,574.44$ & $33,232.94$ & $30,815.09$ \\
\hline Acephate & $22,355.41$ & $26,190.52$ & $19,324.66$ & $24,858.68$ & $27,057.66$ \\
\hline Mineral oil & $28,347.06$ & $25,632.86$ & $25,773.01$ & $27,801.09$ & $26,777.62$ \\
\hline Atrazine & $28,394.91$ & $13,911.37$ & $18,869.47$ & $28,615.70$ & $24,730.90$ \\
\hline Vegetable oil & $14,318.35$ & $16,126.71$ & $18,287.12$ & $17,259.26$ & $13,479.17$ \\
\hline Paraquat Dichloride & - & - & $10,536.60$ & $11,638.19$ & $11,756.39$ \\
\hline Imidacloprid & $7,940.82$ & - & $8,541.55$ & $9,165.97$ & $9,364.57$ \\
\hline Copper hidroxyde & - & - & - & - & $7,443.62$ \\
\hline Chlorpyrifos & $13,084.62$ & $16,452.77$ & $9,187.19$ & $7,271.08$ & - \\
\hline Metomil & $8,533.26$ & $9,801.11$ & - & - & - \\
\hline Diurom & - & $8,579.52$ & - & - & - \\
\hline
\end{tabular}

Source: IBAMA (Instituto Brasileiro do Meio Ambiente e dos Recursos Naturais Renováveis, 2017); ${ }^{\star S a l e s ~ i n ~ t o n s . ~}$

about 57 tons sold in our market. As in 2015 new assets had a greater relevance entering this ranking, paraquate Dichloride, imidacloprid and copper oxide.

Gaboardi et al. (2019) listed a similar reality to the national history, being glyphosate and the most used ingredient in Paraná is its salts, from 2015 to 2016, as well as Pignati et al. (2017), in Mato Grosso from 2012 to 1016, and the authors raised questions about this rising use, associating it with public health problems, increasing the rates of poisoning in consumers and rural workers and environmental and food contamination.

Data on the types of pesticides (herbicides, insecticides or fungicides) and the main ones used are fundamental to associate them with the health effects of the affected areas and the population exposed. Regarding the use of these products, insecticides act to fight insects and lavas, fungicides fight fungi while herbicides fight invasive plants (Gaboardi et al. 2019).

According to the World Health Organization, through the monograph "IARC Monographs on the evaluation of carcinogenic risks to humans - Some organophosphate insecticides and herbicides; Volume 112" (International Agency for Research on Cancer, 2017), Glyphosate that is in the ranking of the most commercialized product is evidenced with carcinogenic potential in humans and animals, being classified as dangerous to the environment, class III, by IBAMA, which is the organ responsible for the activities of analysis, records and control of pesticides in Brazil (Instituto Brasileiro do Meio Ambiente e dos Recursos Naturais Renováveis, 2019).

Glyphosates can be absorbed through the inhalation absorption routes, by ingestion or through the skin, being excreted mainly in the urine and in a lesser amount in the feces. Aminomethylphosphonic acid (AMPA) is the main metabolite generated by the glyphosate kinetics, in which both are distributed throughout the body, where the peak plasma concentration is found mostly after two hours of its administration orally in humans (Rieg, 2016; International Agency for Research on Cancer, 2017)

Among the main acute effects by glyphosate in humans and clinical manifestations present by this intoxication we have: shock, dysrhythmia, tachycardia, alteration of consciousness and mental state, lethargy, dermatological irritations, renal failure, acute lung 
injury, nausea, vomiting, hyperemia of mucous. According to the literature, glyphosate toxicity is considered low LD50 $5.600 \mathrm{mg} / \mathrm{kg}$ (acute oral in rats) and 5,000 $\mathrm{mg} / \mathrm{kg}$ (acute dermal in rats), however, some authors have suggested that this herbicide may have some chronic effects (Toriani, 2017; Melo, 2018).

Among the other products in Table 1, IBAMA classifies the majority as class III (dangerous), as follows: 2,4-D, Mancozebe, Acephate, Vegetable Oil and Imidacloprid, while Atrazine and Chlorpyrifos are class II (very dangerous), and their marketing is prohibited in some European countries. Therefore, they have considerable impact power due to several harmful effects on the environment, animals and humans (Pesticide Properties DataBase, 2019; Instituto Brasileiro do Meio Ambiente e dos Recursos Naturais Renováveis, 2019).

It is noted that the association with high numbers of active ingredients in the market and their great use, comes the possibility of poisoning. Table 2 describes the list of notifications registered for poisoning in Brazil, regarding the ingestion of contaminated food, in the SINAN (Notification Disease Information System) and SINITOX (National Toxic Pharmacological Information System).

The results show the reality of poisoning by food consumption, and in 2017 the largest number of notifications in the SINAN system, following the marketing data that reached a higher average this year.

A certain difference in the data analyzed in both systems, since SINITOX presented relatively inferior data compared to SINAN, and in some years there was no data record, which shows certain fragility in notifications of poisoning, as well as possible underreporting in both realities.

According to Almeida et al. (2017), underreporting is a reality in our country, camouflaging the magnitude of the factor studied. Between 2013 and 2017, 24,148 cases of agricultural pesticide poisoning were reported in SINAN, and suicide attempt poisoning was the most relevant factor reaching 9,444 cases in the study period and ingestion of 143 cases contaminated food, as shown in Table 2. Most reports refer to acute reactions, identified by the health professional, the chronic intoxications, exposures in small quantities of pesticides present in food, that are more difficult to detect due to symptoms and clinical manifestations later (Londres, 2011)

The Food Pesticide Residue Analysis (PARA) program, created and maintained since 2001 by the National Health Surveillance Agency (ANVISA), aims to evaluate the quality of food reaching consumers with an emphasis on pesticide residues. The last PARA report for the 2013-2015 triennium found that
$80.3 \%$ of the analyzed foods were satisfactory, and about these $38.3 \%$ presented residues in the tolerable amount. Regarding the unsatisfactory samples, it was $19.7 \%$, with the majority having pesticide residues not authorized for the crop, followed by extrapolation of the recommended maximum limit (MRL), in both situations (Brasil, 2016a).

According to ANVISA, the irregularities found in the last report of PARA (2013/2015) do not necessarily present health risks, due to the new methodology used in the study, recommended by the World Health Organization/Food and Agriculture Organization of the United Nations (WHO/FAO), which is an acute risk assessment, i.e. poisoning that can occur within 24 hours of eating food containing residues. Therefore, $98.89 \%$ of the samples were not identified as potentially acute risk situations, and in $1.11 \%$ of the monitored samples, a relative acute risk potential was identified (Brasil, 2016a).

However, the difficulty of identifying the extent of the problem to Public Health is evident, since the acute intoxication relation to chronic is unequal, since the easily identified acute intoxication has the reality of underreporting and chronic. They are often not perceived as consequences of pesticide use. Therefore, there is intense consumption with 221 limited records of acute poisoning and almost nonexistent for chronic poisoning (Faria et al. 2009; Londres, 2011).

Ferreira et al.(2018) evaluated the estimated intake of organophosphorus pesticides by the consumption of fruits and vegetables (FV), and concluded in relation to the food intake of the Brazilian population, that for children metidationa exceeded the safety toxicological parameter, however, the article describes that the Brazilian reality has low consumption of FV, and if this consumption reached the recommendations of $\mathrm{WHO}$, six pesticides would exceed the percentage of acceptable daily intake (\% IDA) for children (diazinone, dicofol, dimethoate, metamidophos, metidationa and protiophos) and for adults there would be three (dicofol, metamidophos and methidathione), again evidencing the indiscriminate use of these products.

Studies in other parts of the world have shown similar research on chronic use of contaminated food. In France, Nougadère et al. (2011) evaluated the chronic risk in relation to the consumption of pesticide residues in food, the organophosphates presented a daily intake estimate (EDI) higher than the IDA, and $1.8 \%$ of the active ingredients studied are framed in this reality.

In China, however, through the study by Chen et al. (2011), it was found that $37.7 \%$ of the samples contained insecticides that are considered a serious public health problem for that region.

Table 2. Notifications registered by exogenous intoxication, for food in Brazil.

\begin{tabular}{|c|c|c|c|c|c|c|c|c|c|c|}
\hline \multirow{2}{*}{$\begin{array}{c}\text { YEAR } \\
\text { Region }\end{array}$} & \multicolumn{2}{|c|}{2013} & \multicolumn{2}{|c|}{2014} & \multicolumn{2}{|c|}{2015} & \multicolumn{2}{|c|}{2016} & \multicolumn{2}{|c|}{2017} \\
\hline & SINAN & SINITOX & SINAN & SINITOX & SINAN & SINITOX & SINAN & SINITOX & SINAN & SINITOX \\
\hline NORTH & 7 & 1 & 2 & 0 & 1 & 0 & 3 & 0 & 7 & - \\
\hline MIDWEST & 0 & 2 & 11 & 3 & 6 & 0 & 9 & 1 & 4 & - \\
\hline NORTHEAST & 8 & 2 & 13 & 0 & 4 & 0 & 7 & 6 & 5 & - \\
\hline SOUTHEAST & 7 & 1 & 4 & 0 & 4 & 0 & 4 & 0 & 17 & - \\
\hline SOUTH & 7 & 1 & 2 & 0 & 3 & 0 & 4 & 0 & 4 & - \\
\hline TOTAL & 29 & 7 & 32 & 3 & 18 & $\mathbf{0}$ & 27 & 7 & 37 & - \\
\hline
\end{tabular}

Source: DATASUS (2019); Sinitox (2019). 


\section{Conclusions}

The intense use of pesticides can cause damage to the environment and human health, when ingested it generates a cumulative load of these assets, causing damage to the organism that are sometimes irreversible, since they can be neurological, cancer, endocrine disorders, among others, as described in the literature.

For this, it is necessary to act by the competent bodies to inspect the use and monitor the concentration found in these products, since the chronic use is silent and can later bring losses related to this gradual exposure.

This article served as a data survey to compress the reality in the commercialization of these products and possible errors and excesses of the productive scale. In addition to supporting the next phase of the study, which will be the identification of pesticide residues in fruits samples sold at the local (municipal) level.

It is a reality with scarce data regarding food poisoning, samples above the allowable limit, possibility of chronic consumption and delay in the publication of data on this issue. This makes this topic relevant and stimulating for research, since Brazil still has a vast field of studies to be developed.

\section{References}

Almeida, M. D., Cavendish, T. A., Bueno, P. C., Ervilha, I. C., Gregório, L. D. S., Kanashiro, N. B. O., Rohlfs, D. B., \& Carmo, T. F. M. (2017). A flexibilização da legislação brasileira de agrotóxicos e os riscos à saúde humana: análise do Projeto de Lei no 3.200/2015. Cadernos de Saude Publica, 33(7), e00181016. http://dx.doi.org/10.1590/0102311x00181016. PMid:28767963.

Brasil. (1989). Dispõe sobre a pesquisa, a experimentação, a produção, a embalagem e rotulagem, o transporte, o armazenamento, a comercialização, a propaganda comercial, a utilização, a importação, a exportação, o destino final dos resíduos e embalagens, o registro, a classificação, o controle, a inspeção e a fiscalização de agrotóxicos, seus componentes e afins, e dá outras providências (Lei $\mathrm{n}^{\circ} 7.802$, de 11 de julho de 1989). Diário Oficial [da] República Federativa do Brasil.

Brasil. (2002, January 8). Decreto no 4.074, de 4 de janeiro de 2002. Regulamenta a Lei no 7.802, de 11 de julho de 1989, que dispõe sobre a pesquisa, a experimentação, a produção, a embalagem e rotulagem, o transporte, o armazenamento, a comercialização, a propaganda comercial, a utilização, a importação, a exportação, o destino final dos resíduos e embalagens, o registro, a classificação, o controle, a inspeção e a fiscalização de agrotóxicos, seus componentes e afins, e dá outras providências. Diário Oficial [da] República Federativa do Brasil.

Brasil. Agência Nacional de Vigilância Sanitária - ANVISA. (2016a). Programa de análise de resíduos de agrotóxicos em alimentos PARA - Relatório de atividades de 2013 a 2015. Brasília: ANVISA. Retrieved from http://portal.anvisa.gov.br/documents/111215/0/ Relat\%C3\%B3rio+PARA+2013 2015_VERS\%C3\%83O-FINAL. pdf/494cd7c5-5408-4e6a-b0e5-5098cbf759f8

Brasil. Ministério da Saúde. Secretaria de Vigilância em Saúde. (2016b). Monitoramento de agrotóxicos na água para consumo humano no Brasil, 2014. Boletim Epidemiológico, 47(12), 1-9. Retrieved from http://portalarquivos2.saude.gov.br/images/pdf/2016/marco/23/2015052---Agrot--xicos-publica----o.pdf
Caldas, E. D. (2016). Pesticide poisoning in Brazil. In Encyclopedia of Environmental Health. Reference module in earth systems and environmental sciences (pp. 1-9). USA: Elsevier. http://dx.doi. org/10.1016/B978-0-12-409548-9.10282-9.

Chen, C., Quian, Y., Chen, Q., Tao, C., Li, C., \& Li, Y. (2011). Evaluation of pesticide residues in fruits and vegetables from Xiamen, China. Food Control, 22(7), 1114-1120. https://doi.org/10.1016/j. foodcont.2011.01.007.

Da Ros, J. R. (2019). Falsificação e contrabando de agrotóxicos: a sociedade perde a saúde, o país perde o respeito. Retrieved from http://www.cnpa. embrapa.br/produtos/algodao/publicacoes/trabalhos_cba5/320.pdf

Datasus. (2019) Intoxicação por agrotóxico - Notificações registradas no Sistema de Informação de Agravos de Notificação - SINAN - 2013 a 2017. Retrieved from http://tabnet.datasus.gov.br/cgi/deftohtm. exe?sinannet/cnv/Intoxbr.def.

Faria, N. M. X., Rosa, J. A. R., \& Facchini, L. A. (2009). Intoxicações por agrotóxicos entre trabalhadores rurais de fruticultura, Bento Gonçalves, RS. Revista de Saúde Pública, 43(2), 335-344.

Ferreira, V. B., Silva, T. T. C., Garcia, S., \& Srur, A. U. O. S. (2018). Estimativa de ingestão de agrotóxicos organofosforados pelo consumo de frutas e hortaliças. Cadernos Saúde Coletiva, 26(2), 216-221. http://dx.doi.org/10.1590/1414-462x201800020095.

Gaboardi, S. C., Candiotto, L. Z. P., \& Ramos, L. M. (2019). Perfil do uso de agrotóxicos no Sudoeste do Paraná (2011-2016). Revista NERA, 22(46), 13-40, 2019.

Instituto Brasileiro do Meio Ambiente e dos Recursos Naturais Renováveis - IBAMA. (2017). Boletim de Comercialização de Agrotóxicos e Afins: histórico de vendas 2000-2017. Retrieved from http://www.ibama. gov.br/agrotoxicos/relatorios-de-comercializacao-de-agrotoxicos\# historicodecomercializacao

Instituto Brasileiro do Meio Ambiente e dos Recursos Naturais Renováveis - IBAMA. (2019). Avaliação do Potencial de Periculosidade Ambiental (PPA) de Agrotóxicos e Afins. Brasília: IBAMA. Retrieved from http://agrofit.agricultura.gov.br/agrofit_cons/principal_agrofit_cons

International Agency for Research on Cancer - IARC. (2017). Monographs on the evaluation of carcinogenic risks to humans (Vol. 112: Some Organophosphate Insecticides and Herbicides). Lyon: IARC/WHO.

Klanovicz, J. Ó. (2010). Toxicity and apple production in southern Brazil. História, Ciências, Saúde-Manguinhos, 17(1), 67-85. http:// dx.doi.org/10.1590/s0104-59702010000100005.

Londres, F. (2011). Agrotóxicos no Brasil: um guia para ação em defesa da vida. Rio de Janeiro: Assessoria e Serviços a Projetos em Agricultura Alternativa.

Melo, K. G. (2018). Determinação de glifosato em amostras de urina humana pela derivatização com cloroformato de 9-fluorenilmetilo por cromatografia líquida com detecção por fluorescência (Dissertação de mestrado). Faculdade de Ciências Médicas, Universidade Estadual de Campinas, Campinas.

Nougadère, A., Reninger, J. C., Volatier, J. L., \& Leblanc, J. C. (2011). Chronic dietary risk characterization for pesticide residues: a ranking and scoring method integrating agricultural uses and food contamination data. Food and Chemical Toxicology, 49(7), 14841510. http://dx.doi.org/10.1016/j.fct.2011.03.024. PMid:21421018.

Pelaez, V., Terra, F. H. B., \& Silva, L. R. (2010). A regulamentação dos agrotóxicos no Brasil: entre o poder de mercado e a defesa da saúde e do meio ambiente. Revista de Economia, 36(1), 27-48. http://dx.doi. org/10.5380/re.v36i1.20523.

Pesticide Properties DataBase - PPDB. (2019). The pesticide properties database. A to $Z$ list of pesticide active ingredients. Reino Unido: University of Hertfordshire. Retrieved from http://sitem.herts.ac.uk/ aeru/ppdb/en/index.htm 
Pignati, W. A., Lima, F. A. N. S., Lara, S. S., Correa, M. L. M., Barbosa, J. R., Leão, L. H. C., \& Pignatti, M. G. (2017). Spatial distribution of pesticide use in Brazil: a strategy for Health Surveillance. Ciencia \& Saude Coletiva, 22(10), 3281-3293. http://dx.doi.org/10.1590/1413812320172210.17742017. PMid:29069184.

Rieg, C. E. H. (2016). Consequências da exposição materna à formulação comercial contendo glifosato nos parâmetros bioquímicos e morfológicos em fígado e sangue periférico de ratos imaturos (Dissertação de mestrado). Programa de Pós-graduação em Farmácia, Universidade Federal de Santa Catarina, Florianópolis.

Rigotto, R. (Org.). (2011). Agrotóxicos, trabalho e saúde: vulnerabilidades, resistência no contexto da modernização agrícola no Baixo Jaguaribe - CE. Fortaleza: Edições UFC/Expressão Popular.

Santos, G.B., Ferreira, R.L.A., Schütz, R., \& Zonin, W. J. (2018). Riscos humanos na utilização de agrotóxicos de uma determinada área rural do município de Quatro Pontes - PR, BR. Brazilian Journal of Development, 4(7), 4519-4529.

Silva, H. C. G., \& Costa, J. B. (2018). Intoxicação exógena: casos no estado de Santa Catarina no período de 2011 a 2015. Arquivos Catarinenses de Medicina, 47(3), 2-15.

Sinitox (2019). Fundação Oswaldo Cruz/Centro de Informação Científica e Tecnológica/Sistema Nacional de Informações Tóxico-Farmacológicas. Estatística Anual de Casos de Intoxicação e Envenenamento. Brasil, 2013 - 2017. Retrieved from http://www.fiocruz.br/sinitox

Toriani, S. S. (2017). A influência do organofosforado malation 500 $E C^{\circledR}$ na função hepática, renal e tireoidiana de ratas (Dissertação de mestrado). Programa de Pós-graduação em Saúde e Meio Ambiente, Universidade da Região de Joinville, Joinville.

World Health Organization - WHO. (2010). Exposure to highly hazardous pesticides: a major public health concern. Geneva: WHO. 